УДК 004.896

\section{МУЛЬТИАГЕНТНЕ СЕРЕДОВИЩЕ ПОЕТАПНОГО СИНТЕЗУ СИСТЕМИ ДИНАМІЧНОГО КЕРУВАННЯ У ГНУЧКІЙ ВИРОБНИЧІЙ СИСТЕМІ}

Анотачія: У роботі запропоновано підхід до автоматизаиії прочесу синтезу систем ди намічного керування гнучкими виробничими системами за допомогою мультиагентної моделі із вбудованим реляційним механізмом. Автоматизаиія даного процесу дозволяс уникати впливу суб 'єктивних факторів, пов'язаних із компетениією оператор.

Ключові слова: Система динамічного керування, гнучка виробнича система, інтелектуалізований агент, агентно-орієнтована підсистема, гнучка інтелектуалізована мультиагентна конфігурачія.

\section{Вступ}

Процес функціонування гнучких виробничих систем (ГВС) пов'язаний високим рівнем невизначеності внутрішніх та зовнішніх умов [1]. Продуктивність роботи ГВС в умовах невизначеності напряму залежить від успішної взаємодії ії складових, зокрема транспортної системи та оброблювальних ресурсів. Більшість невизначених ситуацій виникає на оперативному рівні керування системою. У таких умовах особливу увагу слід приділити налагодженню роботи $c$ стеми динамічного керування (СДК), що безпосередньо управляє ходом виробничого процесу.

Визначення 1. Система динамічного керування - підсистема СОУ ГВС, що відповідно до обраного підходу реалізує спланований розклад роботи технологічного устаткування в умовах динамічного виробничого середовища

Твердження 1. Під динамічним виробничим середовищем розуміється таке виробниче середовище, виробничий процес якого відбувається за наявності невизначених подій в реальному часі, що впливають на його хід та/або продуктивність.

Значне різноманіття властивостей СДК дозволяє обрати модель, найбільш адекватну до вимог конкретної ГВС $з$ властивими їй видами невизначених ситуацій. Разом з тим, процес вибору ускладнюється впливом суб’єктивних факторів, пов'язаних з рівнем компетенції оператора, що здійснює налагодження роботи системи динамічного керування.

Задля покращення ситуації, щодо впливу зазначених факторів у [2] було запропоновано і реалізовано наступні кроки:

(ㄷ.С.О.Дьяков, Л. С. Ямпольський
- сформувати набір вирішальних класифікаиійних ознак (НВКО) і створити класифікатор СДК;

- побудувати логічну модель поетапного синтезу (ЛМПС) моделі СДК

- створити узагальнену концептуальну модель СДК на основі набору ітераційних процедур, що забезпечуються складом і послідовністю етапів синтезу.

Наведені кроки дозволили отримати набір всіх можливих варіантів поєднань відповідних значень НВКО, серед яких шляхом багатоітераційного перебирання можна визначити складові умовної бажаної моделі СДК. Враховуючи значну кількість необхідних ітерацій та можливість впливу суб’єктивних людських факторів на даному етапі синтезу СДК виникає необхідність у його автоматизації.

Постановка задачі. Необхідно розробити підхід до автоматизованого синтезу на основі набору ітераційних процедур, такої СДК, яка здатна адекватно задовольняти властивості та обмеження певної ГВС.

У [3] була запропонована можливість використання мультиагентної моделі із вбудованим реляційним механізмом для перебирання на основі ЛМПС функціонально-спеціалізованими інтелектуалізованими агентами (ФСІА) критеріїв обслуговуваності з боку прикладних задач для вибору необхідної топології итучної нейронної сітки (ШНС).

Використаємо наведений у [3] підхід, щоб на основі створеної у [2] віртуальної моделі створити строгу узагальнену модель вибору (УМВ) СДК, що базується на гнучких інтелектуалізованих мультиагентних конфігурачіях (ГІМАК) агентно-орієнтованих підсистем (АОП) для конкретних ГВС.

\section{Узагальнена коншептуальна модель процесу вибору СДК}

Розроблена у [2] віртуальна модель СДК визначає склад і послідовність етапів синтезу системи. Склад етапів синтезу визначає набір вирімальних класифікаиійних ознак, а їх послідовність - логічна модель поетапного синтезу.

Визначення 2. Набір вирішальних класифікаиійних ознак СДК - це така їх мінімально допустима кількість, котра необхідна для формалізації процесу представлення основних властивостей та вибору адекватної СДК, і достатня для обслуговування вимог (критеріїв оцінки) з боку ГВС.

Визначення 3. Логічна модель поетапного синтезу СДК - така послідовність їх перебору у просторі НВКО, котра, будучи виконувана користувачем чи мультиагентною системою автоматизованого вибору (МАПАВ), відтворює 
принципи агентно-орієнтованого підходу і автономно дозволяє виділити СДК, що здатна задовольнити критерії обслуговування ГВС.

Наведений у [2] перелік НВКО є необхідним і достатнім для вирішення поставленої задачі і містить наступні властивості у послідовності згідно з ЛМПС: види невизначеностей у ГВС, підхід до перепланування, стратегія перепланування, політика вибору часу, метод перепланування.

\section{Агентно-орієнтований підхід до ідентифікації моделі СДК}

Основна ідея підходу запропонованого у [3] полягала у тому, щоб, розглядаючи нечіткі ідентифікуючі компоненти як складні агентно-орієнтовані підсистеми (АОП), використати переваги нечіткого підходу до процесу ідентифікації моделі СДК самими АОП

\section{Концепція нечіткої метаідентифікації у задачах вибору Сдк}

Даний підхід полягає в тому, щоб, розглядаючи нечіткі ідентифікуючі компоненти як складні агентно-орієнтовані підсистеми, використати переваги нечіткого підходу до керування процесом ідентифікації самими АОП.

Визначення 4. Метаідентифікеація СДК - це ітераційна процедура синтезу такої СДК, яка виявиться спроможною найкращим чином задовольняти умови обслуговуваної ГВС.

При цьому завдання нечіткої метаідентифікаиії полягає в динамічному побудуванні 3 існуючих функиіонально-спеціалізованих інтелектуалізованих агентіє (ФСІА) таких гнучких інтелектуалізованих мультиагентних конфігурацій (ГІМАК) $A O П$, які найкращим чином задовольняють умови обслуговуваної ГВС

Визначення 5. Інтелектуалізований агент/мультиагент - це програмноапаратний або програмно-емуляційний автономний компонент АОП, який функціонує за певним сценарієм/алгоритмом на основі КУПД в інтересах досягнення поставленої користувачем перед нею мети.

Визначення 6. Агентно-орієнтована підсистема - це складна підсистема ГІМАК, в якій функціонують два або більше ФСІА, орієнтованих на розв'язання задач ідентифікації за певною вирішальною класифікаційною ознакою СДК і утворюючих агентно-орієнтоване середовище.

Визначення 7. Функиіонально-спеціалізований інтелектуалізований агент це IA з функціями метаідентифікації в просторі вирішальних класифікаиійних ознак СДК.

Реалізація вище означеної ідеї можлива за допомогою побудування ГІМАК, особливостями якої є: використання об'єктно-орієнтованих ФСІА різних типів, реалізуючих складові класифікатора СДК; високий ступінь паралелізму; децентралізована структурна і параметрична метаідентифікація в межах АОП (рис. 3).

Для узагальнення підходу розглядається більш складний випадок нечіткої метаідентифікації класифікаційних ознак СДК щодо вимог з боку ГВС. В разі чіткої взаємозалежності «вимога - ознака» реалізація процесу спрощується.

Визначення 8. Гнучка інтелектуалізована мультиагентна конфігурачія така мультиагентна конфігурація, яка: містить агенти $A^{(M)}$ з функиіями метаідентифікації, які реалізують механізм розподіленого динамічного виявлення «ступеня важливості» інших агентів із всілякою природою; формує різні закони ідентифікації; забезпечує паралельність роботи агентів різнорідних «шарів»; реагує на зміни стану зовнішнього середовища (вихідних умов задачі) шляхом піднастроювання загального виходу у відповідності з ідентифікацією, задовольняючою поточний набір умов на вході.

Визначення 9. Агенти з функиіями метаідентифікації - такі ФСІА, які здатні приймати рішення щодо: активації інших агентів ГІМАК; формуванню виведень щодо задоволення поточного набору умов на вході ГІМАК.

Tвердження 2. Сукупність певним чином організованих ФСІА, що забезпечують визначений НВКО рівень ідентифікації СДК, утворюють мультиагентне середовище відповідної АОП [4].

Мультиагентна структура ГІМАК АОП (рис. 1) формується з множини $A=\left\{A_{1}, \ldots, A_{n}\right\}$ зв'язаних між собою ФСІА. На вхід АОП від зовнішніх джерел (в тому числі, і від користувача) надходить множина $U^{(x)}=\left\{U\left(X_{1}\right), \ldots, U\left(X_{k}\right)\right\}$ значень вхідних змінних $X=\left\{X_{1}, \ldots, X_{k}\right\}$, які відображують умови обслуговуваності властивостей (інформаційне поле) прикладної задачі.

Фаззі $(F)$-перетворювач («чіткий $\rightarrow$ нечіткий») трансформує $U^{x}$ у множину факторів $F^{(x)}=\left\{F_{1}^{(x)}, \ldots, F_{l}^{(x)}\right\}$ (є нечіткими множинами, заданими на значеннях вхідних змінних) з відповідними факторами достовірності (ступенями приналежності за експертними оцінками) $C^{(x)}=\left\{C_{1}^{(x)}, \ldots, C_{l}^{(x)}\right\}$. Дефаззі $(D)$-перетворювач («нечіткий $\rightarrow$ чіткий») трансформує множину своїх вхідних факторів $F^{(y)}=\left\{F_{1}^{(y)}, \ldots, F_{p}^{(y)}\right\}$ i відповідних факторів достовірності $C^{(y)}=\left\{C_{1}^{(y)}, \ldots, C_{p}^{(y)}\right\} \quad$ у множину $W^{(x)}=\left\{W\left(Y_{1}\right), \ldots, W\left(Y_{k}\right)\right\} \quad$ значень умов сумісності $Y=\left\{Y_{1}, \ldots, Y_{m}\right\} \quad$ пропоновуваної ГІМАК АОП моделі СДК із заданим на вході набором властивостей ГВС. 


$$
A_{i}=\left(T_{i}, D_{i}, U_{i}, W_{i}, S_{i}, M_{i}, B_{i}, E_{i}\right),
$$

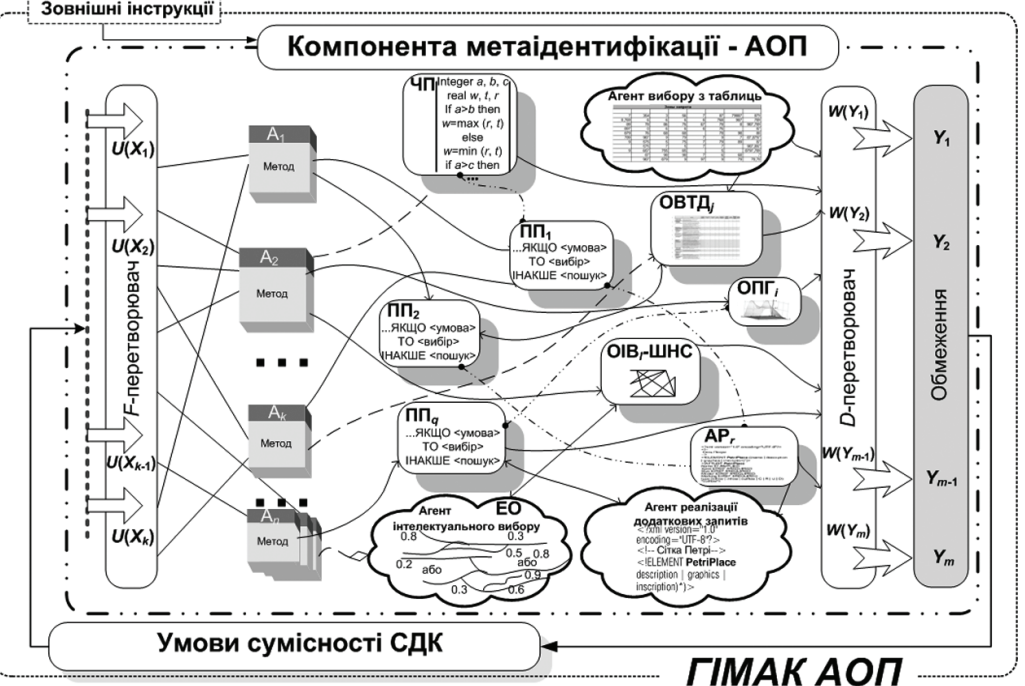

Рис. 1. Структура ГІМАК АОП

\section{Компоненти ГІМАК АОП}

Функціонування ГІМАК АОП формується із загального «внеска» іiі компонент - ФСІА (див. рис. 1): продукційних правил (ПП), експертних оцінок (ЕО), об’єктів інтелектуального вибору ОІВ - штучних нейросіток (ШНС), чисельних процедур (ЧП), об’єктів вибору з табличних даних (ОВТД), об'єктів побудови графіків (ОПГ), реалізації (АР) - якщо експерт або відповідний агент робить висновок щодо необхідності уведення нових правил, обмежень тощо. Базуючись на вхідних даних і меті ідентифікації в залежності від етапу послідовності синтезу моделі СДК, ГІМАК АОП реалізує на виході підхід, стратегію, політику часу, метод і як наслідок - іiі модель СДК, що задовольняє умовам і обмеженням ГВС точності апроксимації, складності реалізації, розмірності та швидкодії, рівню кваліфікації користувача.

Прийнявши за $H$, $G$ відповідно набори (імена) змінних на вході і виході, а за $Z$ - набір з усіх змінних (вхідних і на виході включно), приймаючих участь у міжагентному інформаційному обміні $Z \supset H, Z \supset G$, а також враховуючи, що множина $A=\left\{A_{1}, \ldots, A_{n}\right\}$ взаємозв'язаних ФСІА формує структуру ГІМАК АОП, тоді, використавши множину компонент зі складових $S_{i} \subset S \cup A$ (вхідних відносно цього агента $A_{i}$ ) і дій $M_{i} \subset M \cup A$ (на виході відносно $A_{i}$ ), формальний опис $i$-го агента $A_{i}$ можна подати у вигляді (1): де $T_{i}$ - тип агента (ЕС, НC, ЧП тощо); $D_{i}$ - тип умови для активації (наприклад: $D_{1}-$ зміною вхідних даних агента; $D_{2}-$ естафетною умовою, тобто завершенням поточного прогону визначених попередніх агентів; $D_{3}-$ незалежною активацією, в тому числі відповідно до часового закону; $D_{4}-$ у відповідь на запит від іншого агента, і так далі); $U_{i}, W_{i}$ - набори вхідних і вихідних змінних агента $A_{i}$ відповідно; $B_{i}, E_{i}$ - набори розташованих вище відносно $A_{i}$ (чиї вказівки він виконує) і підлеглих (відносно $A_{i}$ ) агентів відповідно.

\section{Узагальнена модель гнучкої інтелектуалізованої}

мультиагентної системи вибору СДК

Наведена на рис. 2 узагальнена модель гнучкої інтелектуалізованої мультиагентної системи (ГІМАС) об’єднує необхідну для формування алгоритму синтезу СДК і достатню для задоволення вимог з боку обслуговуваної ГВС сукупність цільових компонент метаідентифікації: АОП АОП СДК та інших (за переліком НВКО [2]).

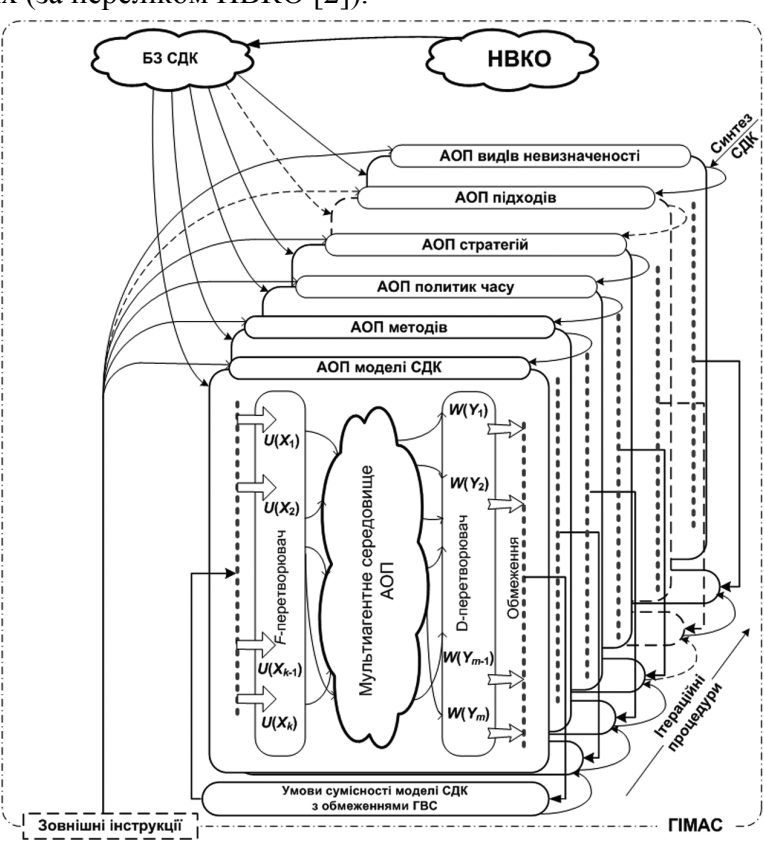

Рис. 2. Узагальнена модель ГІМАС вибору СДК 
Визначення 10. Гнучка інтелектуалізована мультиагентна система - це сукупність ГІМАК АОП, в якій реалізується модель поетапного синтезу СДК з такою послідовністю їх перебирання в просторі НВКО, яка, будучи виконувана користувачем i/aбо внутрішнім ініціюючим джерелом, відтворює принципи агентно-орієнтованого підходу та автономно дозволяє виокремити модель/моделі СДК, здатні задовольнити критерії обслуговування властивостей ГВС.

Заключна процедура поетапного синтезу СДК в ГІМАС зводиться до реляційного перебирання ФСІА умов виконання критеріїв обслуговуваності поточним вектором можливостей конкретної СДК вимог з боку ГВС.

Саме перевірка при реалізації покрокового алгоритму синтезу СДК виконання умов задоволення певною компонентою АОП вимог/обмежень поставленої задачі найчастіше виявляється причиною появи лінгвістичних невизначеностей, опрацювання яких і потребує використання методів і засобів нейро-фаззітехнологій із залученням для розв'язання проблеми процедур фаззіфікаиії та дефаззіфікаиії [5].

Необхідні компоненти для підтримки процесів ідентифікації на кожному з кроків алгоритму синтезу СДК надходять з відповідних баз знань (Б3), а після узгодження з умовами задачі нові реалізації поповнюють ці БЗ, розширюючи таким чином коло ГВС, для яких $\epsilon$ вже готові розв'язки.

\section{Агентно-оріснтований вибір умов}

На рис. 3 приведена УМВ, що заснована на реляційних відношеннях [3] між окремими компонентами НВКО, формування якої являє першу складність реалізації моделі.

Друга складність полягає у кількісному визначенні вагомості реляційних зв'язків між визначальними класифікаційними ознаками і реалізується експертним рейтиновим оцінюванням альтернативних варіантів з використанням методів ранжування і попарних порівнянь [5]. На рис. 3 наведені умовні кількісні результати попередніх обробок даних від джерел, що не претендуючи на строгість експертного оцінювання, можна розглядати в якості прикладу узагальненої методики при вирішенні задачі адекватного синтезу СДК.

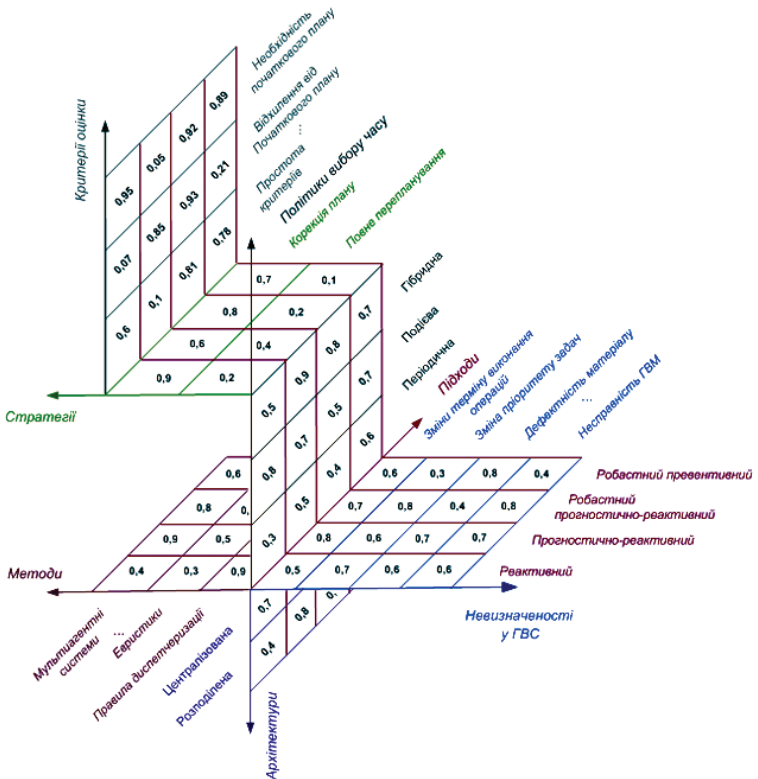

Рис. 3. Інтерпретаційна УМВ СДК

Згідно із [4] АОП функції ФСІА можна реалізувати певними топологіями ШНС. Таким чином, кожний з етапів ЛМПС концептуальної моделі процесу вибору моделі з послідовностями реалізацій у вигляді траєкторій $t r_{\text {орt }}$ руху, визначених повним функціональним орграфом процесу синтезу СДК [2], можна відтворювати топологіями ШНС у вигляді нейросіткової моделі реалізації такого графа (рис. 4).

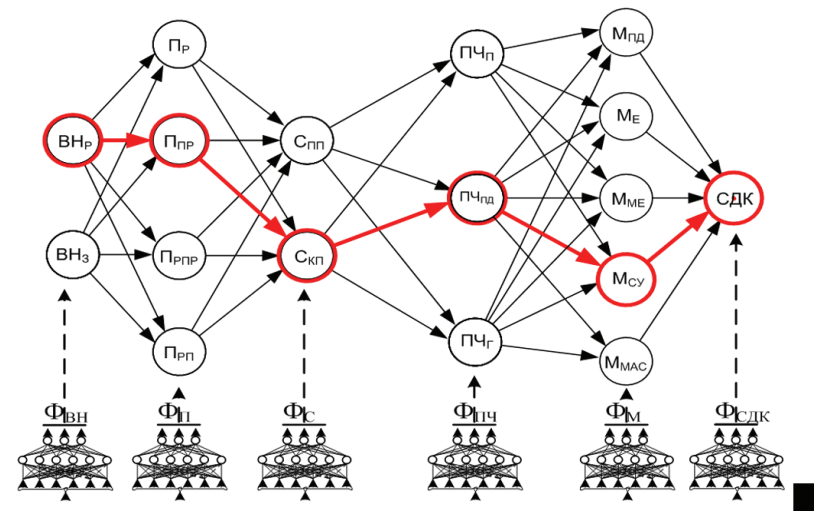

Рис. 4. Нейросіткова модель функціонального орграфа синтезу СДК 
За таких умов процедура синтезу бажаної моделі СДК буде полягати у настроюванні ваг кожної зі складових $\Phi_{\mathrm{BH}}, \Phi_{П}, \Phi_{\mathrm{C}}, \Phi_{П ч}, \Phi_{\mathrm{M}}$ нейросіткової моделі на поточні значення експертних рейтингових оцінювань альтернативних варіантів з урахуванням вагомості реляційних зв'язків (див. рис. 3) згідно вимог ВОМЗ для відповідного етапу синтезу. В решті решт, виконуючи ітераційні процедури настроювання, можна отримати траєкторію $t r_{\text {opt }}$ руху [2], визначувану перетином складових моделей СДК з максимальними до ВОМЗ показниками відповідності. Ті самі міркування в процесі синтезу бажаної моделі СДК стосуються і процедур керування етапами узагальненої моделі ГІМАС (рис. 2).

Як приклад, на рис. 4 червоною лінією виділений слід умовно оптимальної траєкторії $t r_{\text {опт ум }}$ яка в результаті багатоітераційного перебирання визначає складові умовної бажаної моделі СДК (рис. 3)

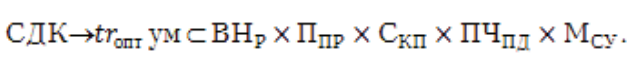

Для впровадження процедури автоматизованого синтезу пропонується включити до СДК окремий модуль автоматизованого синтезу параметрів динамічного керування (рис. 5)

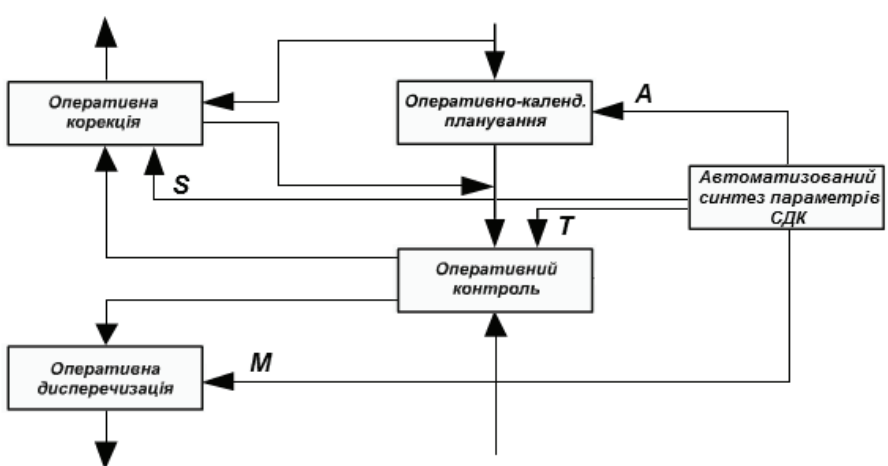

Рис. 5. Модуль автоматизованого синтезу параметрів у структурі СДК

Даний модуль 3 заданою періодичністю опрацьовуватиме отримані від виробничої системи дані про іiі роботу за попередній період та синтезуватиме адекватні до опрацьованих даних параметри роботи СДК. Відповідні параметри будуть передаватися іншим модулям СДК, що визначатиме їх роботу на наступний період. До модуля оперативно-календарного планування передається підхід до динамічного планування (А), до модуля оперативної корекції - стратегія пере- планування (S), до модуля оперативного контролю - політика вибору часу перепланування (Т) і до модуля диспетчеризаиії - метод перепланування (M).

\section{Висновки}

Запропонована в [2] узагальнена концептуальна модель, а також реалізована за допомогою ГІМАС, що містить АОП для кожної властивості з НВКО, інтерпретаційна модель вибору адекватної СДК є основою для реалізації автоматизації цього процесу. Це дозволяє усунути суб'єктивний фактор некомпетентності користувача і реалізувати в автоматизованому виді логічну схему поетапного синтезу СДК.

\section{Список використаних джерел}

1. Дьяков С. О. Динамічне планування у виробничих системах в умовах невизначеності / С. О. Дьяков, Л. С. Ямпольський - Технологічні комплекси, 2014. - 2 (10). - C. 22-26

2. Дьяков С. О. Узагальнена концептуальна модель системи динамічного керування у гнучких виробничих системах / С. О. Дьяков, Л. С. Ямпольський Вісник ЖДТУ. Серія : Технічні науки, 2015. - 1 (72).

3. Ямпольський Л.С. Нечітка ітераційна метаідентифікація штучних нейросіток в мультиагентному середовищі // Вісник кіровоградського національного технічного університету - Кіровоград : КНТУ. - № 26 - 2013. - С. 207-218

4. Ямпольський Л. С. Агентно-орінтована ідентифікація нейронних сіток / Л. С. Ямпольський. - Адаптивні системи автоматичного управління, 2015. $2(27)$.

5. Ямпольский Л. С. Системи штучного інтелекту в плануванні, моделюванні та управлінні : підруч. для студ. вищ. навч. закл. / Л. С. Ямпольський, Б. П. Ткач, О. І. Лісовиченко. - К. : ДП «Вид Дім «Персонал», 2011, - 544 